"several serious deficiencies" in the federal laboratory system, and says laboratories that are no longer fulfilling an important mission should be allowed to close. It makes no mention of specific laboratories, but at a press conference last week Mr Packard said the weapons laboratories at Lawrence Livermore, Sandia and Los Alamos should do less research on

Washington

GOVERNMENT-owned laboratories in the United States should be freed from civil service pay codes so that they can recruit better scientists, and laboratory directors should be given much more control over their own budgets. These are the two main recommendations of a slender report, published last week after a year of work by a committee of the White House Science Council, which is otherwise virtually a carbon copy of earlier studies of the national laboratories published over the past year.

Chaired by David Packard of the Hewlett-Packard Company, the committee was created in March 1982 by presidential science adviser George Keyworth. It was asked at the inaugural meeting of the newly-established White House Science Council to take a "fresh look" at the 755 federal laboratories, which had not been the subject of a comprehensive study for more than two decades. The laboratories, owned by half a dozen separate government departments and occasionally managed by university or private contractors, account for about a third of the whole federal science budget. In 1984 they are expected to spend some $\$ 15,000$ million.

Although clearly one of the most important committees established by the science council, the Packard group decided against a comprehensive report and chose instead to set out a small number of general management principles for the complex of laboratories. The committee visited only 16 laboratories, eight of them belonging to the Department of Energy (DOE), and relied heavily on existing surveys of their work. Unsurprisingly, its conclusions are remarkably similar to those of a study of DOE laboratories published last September by the department's research advisory board (see Nature 12 May, p.101).

Like the research advisory board, the White House committee complains that many of the federal laboratories have diversified too much and need to be given clear and specific missions. It says that much of their work - on engine designs, batteries, fuel cells and renewable energy, for example - could have been done as well or better by the universities or industry. In the case of the DOE laboratories, a surge of work on alternative energy sources, followed by severe cutbacks, had left several major institutions without clear missions.

DOE is also singled out for being more prone than other departments to meddle excessively in its laboratories' detailed management. The Packard committee wants to give laboratory directors more independence by letting them spend between 5 and 10 per cent of their budgets on projects of their own choosing. But they would also be made more accountable, by the establishment of external oversight committees and a greater use of peer review to monitor research quality.

Federal laboratories that are operated as well as owned by the government have a specially difficult time trying to recruit and retain scientific staff of a high calibre, the report maintains. Because they are tied to rigid civil service rules on pay and promotion, the laboratories cannot always reward scientific performance when it is not linked with managerial responsibilities. The committee wants scientific and engineering staff at these laboratories to be exempted from civil service salary policies.

The report claims to have identified energy and more on weapons. And he said Lawrence Berkeley Laboratory, having lost much of its eminence in high-energy physics to Fermilab and the Stanford Linear Accelerator, might wish to define a new mission based on materials research.

At the same press conference, Dr Keyworth gave no hint of disappointment with the committee's work; it had been favourably received by President Reagan and had already been the subject of discussions between the White House science office, the Office of Management and Budget and the heads of government department which maintain federal laboratories. He said the administration regarded implementation of its recommendations as a "high priority".

Peter David

\title{
Foreign relations
}

\section{Silence to save shame}

\section{Washington}

THE Reagan Administration was unable to refrain from patting itself on the back last week when it sent Congress its annual report on scientific relations with other countries. A covering letter from President Reagan pointed out that for the first time, scientific cooperation had been on the agendas of the international economic summits at Versailles and Williamsburg. The letter also noted that new scientific agreements have been concluded with India and Brazil and an old one, with China, considerably expanded. What the letter did not say was that the Office of Management and Budget (OMB) wants the report it accompanied - the only detailed study of how science affects US diplomacy - to be the last ever published.

Congress compelled the State Department to produce the annual report by writing a new section - Title V - into the Foreign Relations Authorization Act in 1978. The State Department was expected to provide a careful analysis of the part science and technology play in relations with other countries. Since the Title V reports began to emerge in 1980 , however, they have generated more heat between Congress and the State Department than shed light on US thinking on international scientific relations.

Last year, the House of Representatives Foreign Affairs Committee was so dismayed by the vapidity of the report that it printed it with an unflattering critique provided by the Congressional Research Service. According to this agency, the report avoided candid discussion of the foreign policy or diplomatic content of most of the activities described. Thus the withdrawal of the National Aeronautics and Space Administration from the International Solar Polar Mission was reported without mentioning the serious diplomatic repercussions, and a discussion of transboundary pollution between the United States and Canada did not refer to the impact of the acid rain debate on relations between the two countries.

This year's report does little better. A section describing the role of the United States at the United Nations' 1982 Unispace meeting in Vienna says the United States was able to demonstrate its preeminence in space applications, but does not hint that the meeting was widely viewed as a diplomatic rout for the United States (see Nature 21 April, p.646).

Congressional critics of the quality of Title $\mathrm{V}$ reports want to see them improved, not eliminated. It has therefore come as a surprise to the House Foreign Affairs Committee and the Committee on Science and Technology that OMB wants the Title $V$ reporting requirement deleted altogether. The Title $V$ reports survived the administration's purge of annual reports in last year's Congressional Reports Reduction Act, but OMB now claims that they merely duplicate the science and technology reports produced by the $\mathrm{Na}$ tional Science Foundation.

Congress is likely to disagree. John Holmfeld, a staff official on the Science and Technology Committee, said most members regard Title $\mathrm{V}$ as an important way to remind the State Department of the scientific dimension in international relations.

Peter David 